PNL-2590

UC-70

\title{
Criticality Safety Comparisons of Spent Fuel Facility Concepts
}

S. W. Heaberlin

G. P. Selby

September 1978

Prepared for the U.S. Department of Energy under Contract EY-76-C-06-1830

Pacific Northwest Laboratory Operated for the U.S. Department of Energy by 


\title{
NOTICE
}

This report was prepareci as an account of work sponsored by the United States Government. Neither the United States nor the Department of Energy, nor any of their employees, nor any of their contractors, subcontractors, or their emclcyees, makes ary warranty, express or implied, or assumes any legal liability of responsibility for the accuracy sompleteness or usefulness of any information, apparatus, product or process disclostd, or represents that its use would not infringe privarely owned rights.

The views opmions and conclusions contained in this report are those of the contractor and do not recsusarily represent those of the United States Covernment or the United States Department of Energy.

\author{
PACIFIC NORTHWEST LABORATORY \\ operated by \\ BATTELLE \\ for the \\ UNITED STATES DEPARTMENT OF ENERGY \\ Under Contract EY-76-C-06-7330
}
Prinir-d in the United States of America Available from
National Tecturical Intormation Service
United States Department of Commerce 3285 ?ort Royal Road
Sprinctield, Virginia 2215

Price. Printed Coprs

$\therefore$ Microfiche $\$ 3.00$

\begin{tabular}{|c|c|}
\hline - Page: & $\begin{array}{c}\text { NTis } \\
\text { Sellin' Price }\end{array}$ \\
\hline Wi-uts & 54.00 \\
\hline $025-050$ & 5450 \\
\hline 051079 & $53: 25$ \\
\hline $675=+\infty 0$ & 56.00 \\
\hline $701-125$ & 25.50 \\
\hline $125-150$ & 57.25 \\
\hline $151-175$ & 58,00 \\
\hline 776.217 & 59.00 \\
\hline 41.225 & 39.25 \\
\hline $2.6-150$ & 5950 \\
\hline $251-275$ & 510.5 \\
\hline 205,300 & 511.00 \\
\hline
\end{tabular}




\section{0}

CRITICALITY SAFETY COMPARISONS

OF SPENT FUEL FACILITY CONCEPTS

S. W. Heaberl in

G. P. Selby

September 1978

Prepared for

the U.S. Department of Energy under Contract EY-76-C-06-1830

Pacific Northwest Laboratory

Richland, Washington 99352 


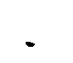

. 


\section{TABLE OF CONTENTS}

1.0 INTRODUCTION . . . . . . . . . . . . . . . . . . . . . . . 1

2.0 SUMMARY . . . . . . . . . . . . . . . . . . . 2

3.0 METHODŚ . . . . . . . . . . . . . . . . . . . . 3

4.0 SINGLE CANISTER CONCEPTS . . . . . . . . . . . . . . . . . . . 4

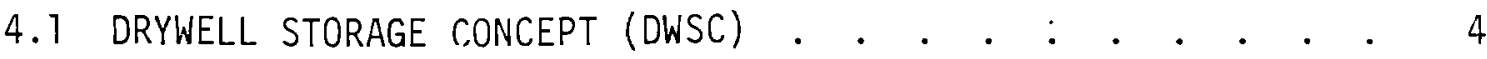

4.2 SEALED STORAGE CASK CONCEPT - $1($ SSCC-1) . . . . . . . 5

4.3 SEALED STORAGE CASK CONCEPT - RSSF (SSCC - RSSF) . . . . 6

5.0 MULTIPLE CANISTER CONCEPTS . . . . . . . . . . . . . . . . . . 6

5.1 SEALED STORAGE CASK CONCEPT - $2($ SSCC-2) . . . . . . . . 6

5.2 DRYWELL WITH SUPPLEMENTAL COOLING (DWSC-2) . . . . . . 7

5.3 AIR COOLED VAULT CONCEPT (ACVC) . . . . . . . . . . 8

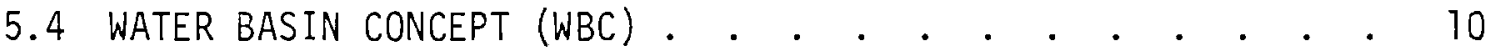

6.0 CONCLUSIONS . . . . . . . . . . . . . . . . . . . . . . 13 REFERENCES . . . . . . . . . . . . . . . . . . . 15

APPENDIX A . . . . . . . . . . . . . . . . . . . A-2

APPENDIX B . . . . . . . . . . . . . . . . . . . . B-2 


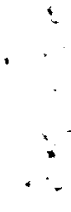




\section{LIST OF FIGURES}

1. Reactivity of FWSC-2 for Low Density Interspersed Water KENO-IV . . . . . . . . . . . . . . . . . 9

2. Reactivity of ACVC for Low Density Interspersed Water KENO-IV. . . . . . . . . . . . . . . . . 11

B.1 Drywell Geometry Model, Flooded . . . . . . . . . . B-3

B.2 SSCC-1 Geometry Model, Canister Flooded . . . . . . . . B-3

B.3 SSCC-2 Geometry Model, Canisters Flooded . . . . . . . B-4

B.4 DWSC-2 Geometry Mode7, Canisters Flooded . . . . . . . . . B-5

B.5 ACVC Geometry Model, One Flooded Canister (PWR) . . . . . . B-5

B.6 ACVC Geometry Mode1, One Flooded Canister (BWR) . . . . . . B-6

\section{LIST OF TABLES}

1. SSCC-2 With Intact Canisters and Interspersed $\mathrm{H}_{2} \mathrm{O}$. . . . . . 7

2. DWSC-2 With Intact Canisters and Interspersed $\mathrm{H}_{2} \mathrm{O}$. . . . . . 8

3. ACVC With Intact Canister and Insterspersed $\mathrm{H}_{2}{ }^{0}$. . . . . . 10

4. Fuel Storage Rack Spacings . . . . . . . . . . . 12 


\subsection{INTRODUCTION}

Recent changes in U.S. domestic nuclear energy policies have deferred indefinitely the reprocessing of spent nuclear fuel. Consideration is therefore being given to the retrievable storage of spent fuel. The Spent Fuel Handling and Packaging program has as its goal the design and eventual construction of a facility to store the increasing inventory of spent fuei. Seven storage concepts have been proposed. (1) In evaluating the suitability of these concepts, many features must be examined. Since a significant amount of fissile material is still contained in the unreprocessed fuel, nuclear criticality safety is one of the items of concern. The purpose of this study is to provide a comparison of the concepts from the viewpoint of criticality safety.

The seven concepts considered are:

Drywe 11 Storage Concept (DWSC)

Sealed Storage Cask Concept-1 (SSCC-1)

Sealed Storage Cask Concept-RSSF (SSCC-RSSF)

Sealed Storage Cask Concept-2 (SSCC-2)

Drywe 11 With Supplemental Cooling (DWSC-2)

Air Cooled Vault Concept (ACVC)

Water Basin Concept (WBC)

It is important to emphasize that this study is a comparison. No attempt was made to demonstrate safety by finding the absolute worse cases for each concept. Rather, a set of conservative conditions was applied to a 11 concepts allowing a basis for comparison between them. Likewise, in some instances, results from this study due to its conservatism would imply an unsafe situation for a given concept, whereas detailed analysis of an actual design may show it to be acceptable.

With the relatively long storage times involved (25-100 yars), the possibility of abnormal conditions should be considered. One major assumption carried through the study is that water is allowed to enter the storage package. Water floods of casks and vaults, as well as intrusion of low 
density water was also allowed. Consideration was given to both intact fuel rods and fine powder which could result from rod disintegration.

\subsection{SUMMARY}

The seven storage concepts were analyzed from the viewpoint of nuclear criticality safety. While the analysis is not adequate for use in licensing, it provides an adequate basis for comparison. All concepts, with the exception of the water basin, were assumed to use the same canister type. This 13-in. ID cylinder contains one PWR assembly (Westinghouse $17 \times 17$ ) which is composed of fresh $\mathrm{UO}_{2}$ fuel enriched to $3.5 \mathrm{wt} \%{ }^{235} \mathrm{U}$. Canister failure and water intrusion were allowed. Consideration was also given to fuel rod disintegration due to $\mathrm{UO}_{2}$ oxidation. The basic assumptions and methods are described in the next section. Details of the analysis and the results are given in the following sections.

For the case of intact fuel rods, the single canister concepts are preferred from the viewpoint of criticality safety. The SSCC-1 would be the best choice followed by the SSCC-RSSF, and next the Drywe11. For the multiple canister concepts the order of preference is DWSC-2, SSCC-2, and ACVC. For intact fuel rods al1 concepts are potentially licensable, however the SSCC-2 and ACVC may be questionable.

The disintegration of fuel rods poses a safety problem for all concepts. (a) While one concept could be more reactive than another, the difference is smal1. As described none of the concepts (a) would be acceptable uniess:

- Disintegration is shown to be incredible, or

- Water intrusion is shown to be incredible.

Canister redesign and/or less restrictive assumptions (allowing credit for burnup for instance) might yield a safe design even if the two items above cannot be met.

(a) The Water Basin Concept is an exception since fuel rod disintegration is not considered to be a problem for that type of storage. 


\subsection{METHODS}

The object of this study was to provide a criticality safety comparison of the spent fuel storage concepts described in Reference 1. Therefore, rather than a detailed study into each concept to determine the special condition which would constitute the worst credible case for it, a standard set of assumed conditions was applied to all concepts. Comparisons are generally made on the basis of the effective multiplication factor $k_{\text {eff }}$. A critical system will have $k_{\text {eff }}$ equal to one. Values less than one are subcritical. A common practice is to not allow $k_{\text {eff }}$ to exceed 0.95 to provide an adequate safety margin.

Each concept was assumed to contain a single PWR assembly containing $\mathrm{UO}_{2}$ enriched to $3.5 \mathrm{wt} \%{ }^{235} \mathrm{U}$. It was shown that using a single PWR assembly is conservative when compared to three BWR assemblies (see Sections 4.1 and 5.3). The BWR fuel was assumed to be enriched to $2.6 \mathrm{wt} \%{ }^{235} \mathrm{U}$. No credit was taken for fission products or fissile depletion. The assembly sizes used were that of the Westinghouse $17 \times 17$ and the General Electric $8 \times 8$ for the PWR and BWR respectively. It was assumed each concept used the same 13-in. ID (PWR) or 17-in. ID (BWR) helium filled canister. These canisters are sealed and leak checked. However, with the long storage times (25-100 years) and potentially large number of canisters $(>50,000)$, the possibility of canister leakage and water intrusion must be considered. This study assumes the canisters fail and water completely fills them.

Another abnormal condition considered was the possibility of fuel rod disintegration. This phenomenon, which is caused by $\mathrm{UO}_{2}$ oxidation at elevated temperatures, can reduce fuel rods to fine powder. This condition was treated as $\mathrm{UO}_{2}$ in water at optimum moderation $\left(2400 \mathrm{~g} \mathrm{UO}_{2} / \mathrm{l}\right)$. The optimum moderation condition was assumed because the amount of water in the canister would not be controlled.

Along with the disintegration cases intact fuel rods were also considered. These were taken as 0.323-in. pellet diameter fuel rods (standard Westinghouse $17 \times 17$ ) at optimum water to fuel volume ratio. This optimization was used because after irradiation and transportation the rod pitch could not be guaranteed to be the original as built values. This is a conservative assumption. 
Various neutron reflection conditions were applied to the various concepts. For single canister concepts, these amounted to the actual or a conservative approximation to the material surrounding the package. For multiple canister concepts, the possibility of filling the entire storage area with water introduced full water reflection cases. An infinite thickness of surrounding water can be approximated by 6 inches in the calculations. In all concepts, the steel canister walls were neglected.

For multiple canister concepts, the possibility of essentially dry canisters with interspersed water between them was also considered. The fuel material was modeled as homogeneous $\mathrm{UO}_{2}$ at the smear density of a PWR (Westinghouse $17 \times 17$ ) assembly with 1 wt\% water. The 1 wt\% water was included to account for residual moderators in the fuel assembly. This is likely to be quite conservative, however since the goal in the study is comparison, the conservatism should not generate concern. The density of the interspersed water was optimzed for each of the multiple canister concepts.

A11 of the calculations were performed with the KENO-IV Monte Carlo code. ${ }^{(2)}$ Neutron cross sections were prepared with the EGGNIT-II ${ }^{(3)}$ code using processed ENDF/B-IV neutron cross section data.

\subsection{SINGLE CANISTER CONCEPTS}

Three of the seven concepts place each fuel assembly in a position that isolates it from all the others, using earth or concrete for shielding. They are the Drywe11, the Sealed Storage Cask Concept-1, and the Sealed Storage Cask Concept-RSSF. Individual discussions of the single canister concepts follow below.

\subsection{DRYWELL}

The drywe11 (PWR consists of a 16-in. diameter vertical hole in the ground with a 3/8-in. wal1, 16-in. 0.D. steel pipe fitting tightly inside. A 2-ft layer of grout is poured in the bottom and a fuel assembly canister is placed on it (0.D. $=14$ inches, leaving 5/8-in. radial clearance). The hole is then plugged with a $7-\mathrm{ft}$ concrete plug. 
The worse case evaluated was a full water flood in the pipe, the canister and the soil. The compositions of the soils and concrete used are given in Appendix $A$. The computer model that was used was somewhat simplified. A drawing of the geometry model used is given in Figure B. 1 of Appendix B. The steel was eliminated, leaving the fuel element in a 16-in. diameter cylinder of water, surrounded by water-laden soil. The resultant reactivity for intact fuel rods was $k_{\text {eff }}=0.935 \pm 0.005$ for $30 \mathrm{vol}^{2} \mathrm{H}_{2} \mathrm{O}$ in soil. For $40 \mathrm{vol}^{\%} \mathrm{H}_{2} \mathrm{O}$ in the soil, the reactivity is $\mathrm{k}_{\text {eff }}=0.924 \pm 0.004$.

In the case of the BWR drywell, the hole is $20 \mathrm{in}$. in diameter, with the 17-in. ID BWR canister size. This contains three BWR assembiies. The results for a full flood condition with intact rods are: $k_{\text {eff }}=0.860 \pm 0.005$, with 40 vol\% $\mathrm{H}_{2} \mathrm{O}$ in the surrounding soil. The PWR application of this concept is clearly less reactive than the PWR.

If the fuel has disintegrated and mixed with water while the canister and soil are flooded. then the PWR case will approximate a 13-in. cylinder of solution with full water reflection. Assuming optimum solution, $2400 \mathrm{~g} \mathrm{UO}_{2} / l$, the reactivity is $\mathrm{k}_{\text {eff }}=1.055 \pm 0.006$.

\subsection{SEALED STORAGE CASK CONCEPT-1 (SSCC-1)}

The SSCC-1 (PWR) is a concrete cask surrounding a single canister. The cask is an annulus $40 \mathrm{in}$. thick, with its inner surface $4 \mathrm{in}$. from the canister. There is more concrete above and below the canister. A horizontal cross section of this geometry is shown in Figure B.2.

This concept is geometrically very similar to the drywell; the two significant differences are the nature of and the distance to the reflector. The reactivity of the SSCC- 1 with only the canister flooded is $k_{\text {eff }}=0.929 \pm$ 0.005 . With the associated statistical deviations, this value is equivalent to the drywe1l. If both the cask and canister are flooded, the fuel has essentially full water reflection, a case which has $k_{\text {eff }}=0.943 \pm 0.005$.

In case of rod disintegration, if the cask and canister are both flooded, then the situation may be approximated by full water reflection, which gives $k_{\text {eff }}=1.055 \pm 0.006$. If the cask is not flooded, the reactivity is about the same, $k_{\text {eff }}=1.051 \pm 0.006$. 


\subsection{SEALED STORAGE CASK CONCEPT - RSSF (SSCC-RSSF)}

This concept is based on the Retrievable Surface Storage Facility (RSSF) above ground casks. Its design is somewhat similar to the SSCC-1.

The canister is enclosed in an overpack (a slightly bigger canister), which is loaded into the concrete cask. For heat transfer reasons, there are natural convection air passages bringing in outside air and channeling it past the overpack.

From a criticality safety standpoint, the cases analyzed for the SSCC-1 can be applied to the SSCC-RSSF. Data on overpack size and inner annulus diameter were not available. It was assumed these dimensions would not make the SSCC-RSSF significantly different from the SSCC-1. Therefore no additional calculations were performed.

\subsection{MULTIPLE CANISTER CONCEPTS}

Four of the seven concepts involve more than one fuel assembly per location. They are: the Sealed Storage Cask Concept-2, with six assemblies in one containment vessel; the Drywell with Supplemental Cooling, with ten assemblies; the Air-Cooled Vault Concept, with 500 assemblies per vault, and the Water Basin Concept, which has over 4000 assemblies per basin. Individual discussions of each of the multiple canister concepts follow below.

\section{1 SEALED STORAGE CASK CONCEPT-2 (SSCC-2)}

The SSCC-2 is similar to SSCC- 1 in that the shield is a thick concrete annulus. The SSCC-2, however, is larger, with an inside radius of 29 inches. Inside are six canisters arrayed with their centers on a 36-in. diameter circle concentric with the annulus.

The only simplification made in the computer model was a change from rectangular fuel assemblies to cylindrical, preserving cross-sectional area and volume. This assumption should have a minimal effect on reactivity. A horizontal cross-section of one quadrant of SSCC-2 with flooded canisters is shown in Figure B.3. 
A full flood of the cask and all canisters nearly isolates each assembly, so each one is surrounded by an effectively infinite water reflector. The reactivity for the infinite water reflection case is $k_{\text {eff }}=0.943 \pm 0.005$. The full flood of SSCC- 2 results in $k_{\text {eff }}=0.942 \pm 0.005$.

A worse case is the draining of the cask while the canisters remain flooded, resulting in $k_{\text {eff }}=0.985 \pm 0.006$. This is the worst case evaluated.

The reactivity of SSCC- 2 with the canisters intact and the cask filled with interspersed water (heavy fog). is given in Table 1.

TABLE 1. SSCC-2 with Intact Canisters and Interspersed $\mathrm{H}_{2} \mathrm{O}$

$\begin{array}{cc}\mathrm{H}_{2} \mathrm{O} \text { Density, } \mathrm{g} / \mathrm{cm}^{3} & \underline{k_{\text {eff }}} \\ 0.03 & 0.370 \pm 0.007 \\ 0.05 & 0.380 \pm 0.007 \\ 0.07 & 0.396 \pm 0.005 \\ 0.09 & 0.389 \pm 0.005\end{array}$

The reactivity peaks at about $0.07 \mathrm{~g} / \mathrm{cm}^{3}$ water with $k_{\text {eff }}=0.396 \pm 0.005$. These very low values occur because only six fuel assemblies are involved.

\subsection{DRYWELL WITH SUPPLEMENTAL COOLING (DWSC-2)}

DWSC-2, the drywell concept with heat pipes, isolates ten canisters in a single concrete vault. The canisters are arranged in two parallel rows of five, $6 \mathrm{ft}$ apart center-to-center. Within rows, the canisters are spaced on 3-ft centers.

The major simplification made in the computer model used was the elimination of the heat pipes. A plot of the model appears in Figure B.4.

Since one foot of water is enough for full neutronic isolation, a full water flood isolates each canister. If the basin is flooded the worst that could then happen is concurrent flooding of a canister, resulting in an infinite water reflection case with $k_{\text {eff }}=0.943 \pm 0.005$. 
With the canisters still flooded but the vault drained, $k_{\text {eff }}=0.944 \pm$ 0.005. This is essentially the same as the vault flood case. The draining of the vault introduced two competing effects. These are an increase in interaction between assemblies versus descreased reflection. These effects balanced each other out.

The reactivities for intact canisters and interspersed water in the vault are shown in Table 2, and displayed in Figure 1.

TABLE 2. DWSC-2 with Intact Canisters and Interspersed $\mathrm{H}_{2} \mathrm{O}$

$\begin{array}{cc}\mathrm{H}_{2} \text { O Density, } \mathrm{g} / \mathrm{cm}^{3} & \underline{k_{\text {eff }}} \\ 0.01 & 0.483 \pm 0.006 \\ 0.02 & 0.540 \pm 0.006 \\ 0.03 & 0.570 \pm 0.007 \\ 0.05 & 0.542 \pm 0.006 \\ 0.07 & 0.515 \pm 0.007 \\ 0.09 & 0.478 \pm 0.005\end{array}$

The condition of greatest reactivity is $0.03 \mathrm{~g} / \mathrm{cm}^{3} \mathrm{H}_{2} 0$; again, the values are low because of the small number of assemblies involved (ten).

\subsection{AIR COOLED VAULT CONCEPT (ACVC)}

The air cooled vault contains 500 assemblies in five blocks of 100 each ( $10 \times 10$ square, $3-\mathrm{ft}$ centers). The blocks are in a row, with $6 \mathrm{ft}$ between blocks (center-to-center; essentially, one row is skipped). Each assembly is in a standard canister, which is enclosed in a slightly larger steel overpack canister. Above and below the overpack array are $3 \mathrm{ft}$ of air space, followed by concrete.

For the purpose of computer modeling, the conservative assumption of an infinite two-dimensional array was made. A plot of the model, a horizontal cross-section of one (flooded) canister and its surrounding space is shown in Figure B.5.

For the case of a full flood of the vault and canisters, the result is again full water reflection with reactivity $k_{\text {eff }}=0.943 \pm 0.005$. 


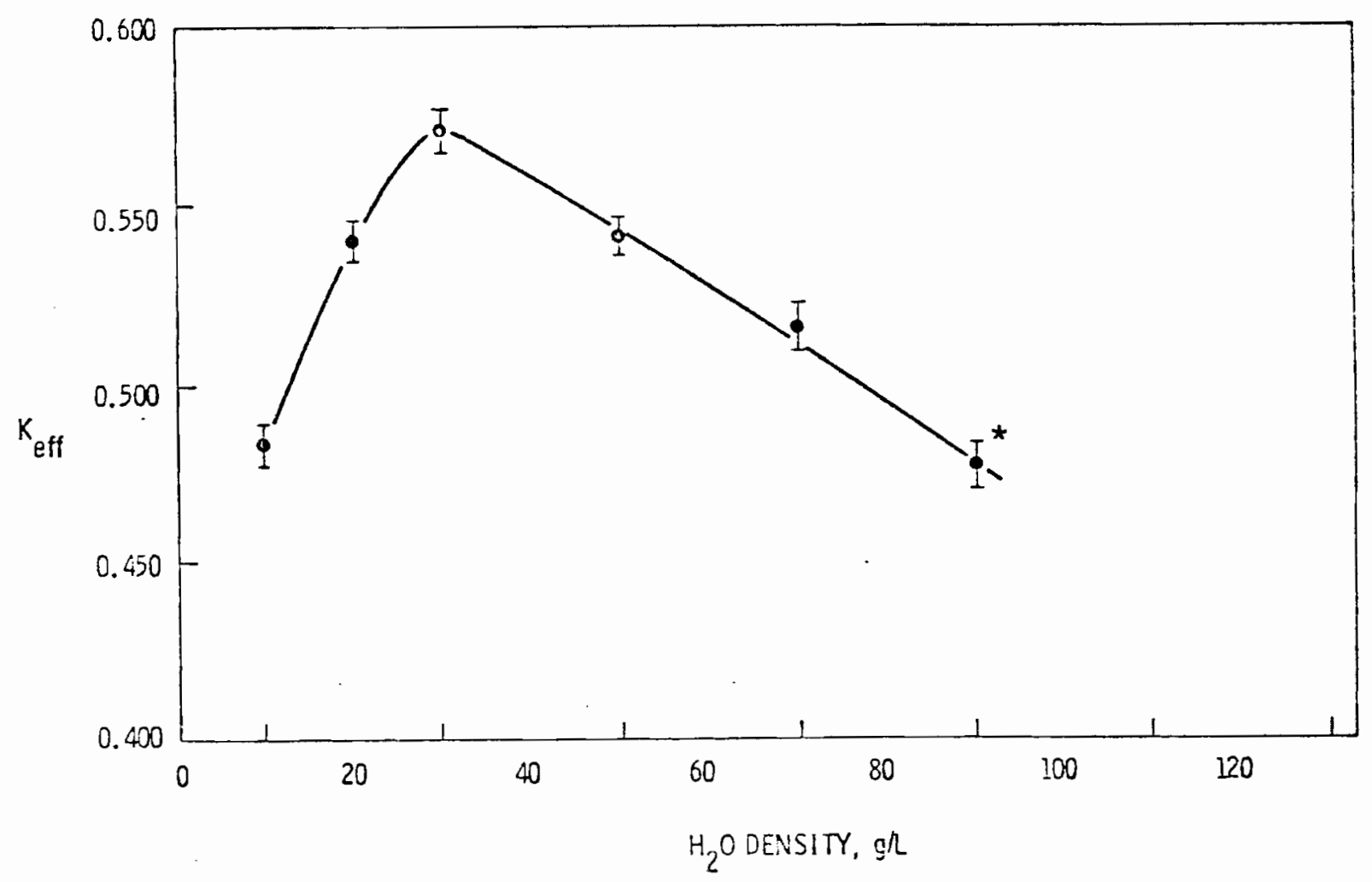

FIGURE 1. Reactivity of DWSC-2 for Low Density Interspersed Water-KENO-IV

* Error bars indicate one standard deviation. 
Leaving the canisters flooded while draining the vault results in a worse case, with $k_{\text {eff }}=1.028 \pm 0.007$. For comparison, the same situation with BWR fuel has $k_{\text {eff }}=0.889 \pm 0.004$. A BWR geometry appears in Figure B.6.

Table 3 gives reactivity for cases of interspersed $\mathrm{H}_{2} \mathrm{O}$ and intact canisters. These data are presented graphically in Figure 2.

TABLE 3. ACVC with Intact Canisters and Interspersed $\mathrm{H}_{2} \mathrm{O}$

\begin{tabular}{cc} 
Density $\mathrm{H}_{2} \mathrm{O}, \mathrm{g} / \mathrm{cm}^{3}$ & $\underline{k_{\text {eff }}}$ \\
\cline { 1 - 2 } 0.01 & $1.003 \pm 0.008$ \\
0.02 & $1.073 \pm 0.006$ \\
0.03 & $1.064 \pm 0.007$ \\
0.04 & $1.058 \pm 0.007$ \\
0.05 & $1.016 \pm 0.006$ \\
0.07 & $0.906 \pm 0.007$ \\
0.09 & $0.804 \pm 0.007$
\end{tabular}

The highest reactivity is at $0.02 \mathrm{~g} / \mathrm{cm}^{3}$ interspersed water density. This value is much higher than the peak values for the SSCC-2 and DWSC-2 interspersed water cases. This is caused by the much larger number of interacting canisters.

\subsection{WATER BASIN CONCEPT (WBC)}

This concept is included for reference purposes only, since it is not a passive system. The reference design of the WBC calls for assemblies stored in racks within a large water pool. The water provides radiation shielding and a cooling medium. The water is pumped through heat exchangers, venting the thermal energy to the environment. The design calls for PWR assemblies to be stored on 15-in. by 15-in. grids. BWR assemblies would be stored on 8-in. by 8-in. grids. Fixed neutron poisons would not be used.

Since storage of spent fuel in water basins is an established technology, no calculations were performed on this design. Comparisons can be 


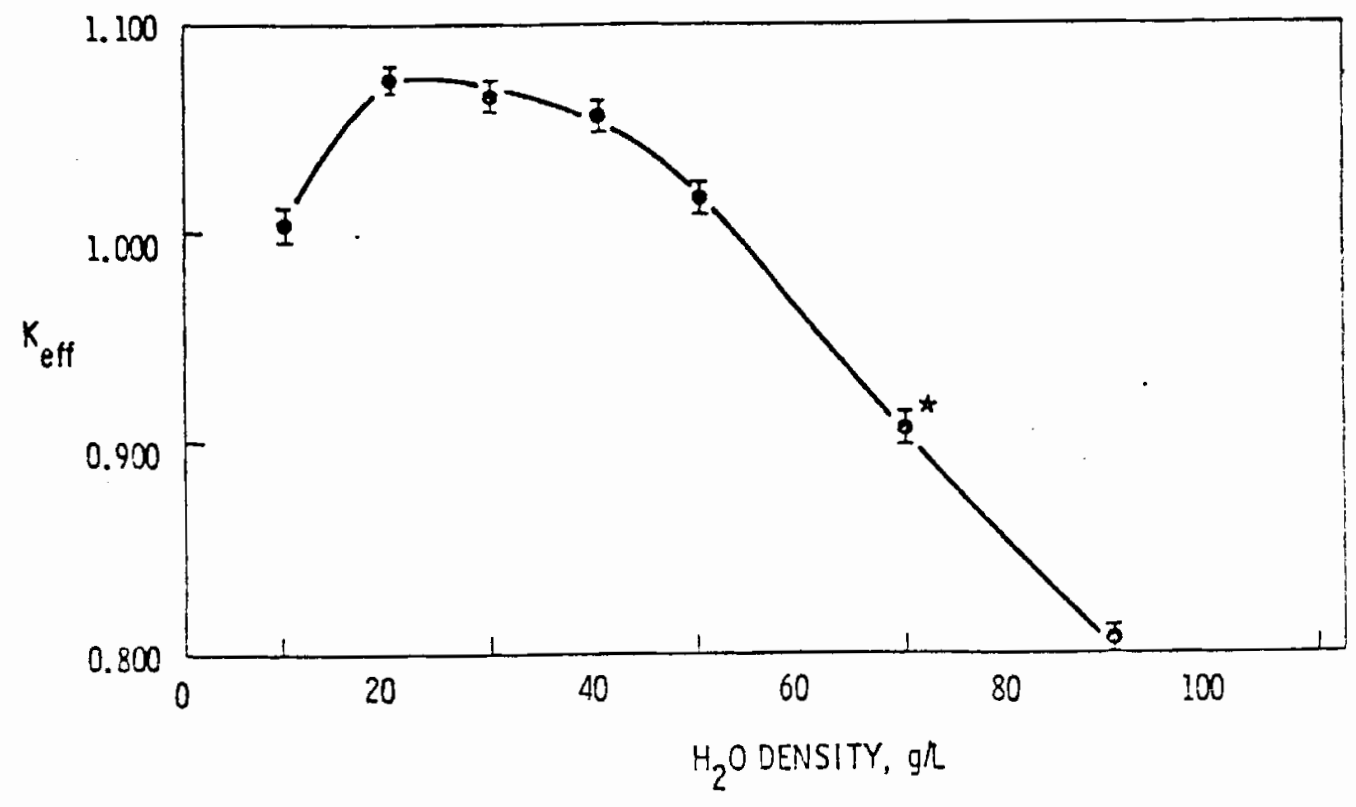

FIGURE 2. Reactivity of ACVC for Low Density Interspersed Water-KENO-IV

* Error bars indicate one standard deviation. 
made to existing basins. Table 4 shows the rack spacing for a BWR and PWR basin. The original values were probably quite conservative. Reducing conservatism and adding stainless steel to the racks allows a significant reduction in spacing. Addition of boron as a neutron poison allows greater reduction.

TABLE 4. Fuel Storage Rack Spacings (4)

\begin{tabular}{lcc} 
& $\begin{array}{c}\text { Three Mile Island } \\
\text { PWR }\end{array}$ & $\begin{array}{c}\text { Dresden } \\
\text { BWR }\end{array}$ \\
\cline { 2 - 2 } & 21.0 & 10.0 \\
Original, inches & 13.0 & 7.3 \\
$\begin{array}{l}\text { Stainless steel, } \\
\text { inches }\end{array}$ & 10.5 & \\
$\begin{array}{c}\text { Stainless steel } \\
\text { boron, inches }\end{array}$ & & 6.5
\end{tabular}

The spacing given in Table 4 indicates that the proposed 15-in. and 8-in. spacing could be a little optimistic. However, a small increase in spacing or use of steel plates could resolve potential criticality safety questions.

The problem of fuel rod disintegration does not arise in water basin storage. The lower fuel temperature essentially precludes the oxidation reaction. Even if disintegration were to occur the combination of large area for dispersion and quick detection would render the problem mute.

In general, the water basin concept generates no reasonably unresolvable criticality safety concerns. While any given basin design requires rigorous demonstration of safety, the existing experience with water basin storage shows that such demonstration is possible. 


\subsection{CONCLUSIONS}

In making comparisons between spent fuel storage concepts, a division should be made between intact fuel rods and disintegrated fuel rod cases.

For intact fuel rods the single canister concepts have a slight advantage over the multiple canister concepts in their slightly lower reactivities. For this reason the single canister concepts would be favored from a criticality safety viewpoint. Although all three of these concepts have approximately equal reactivities the SSCC-1 would be preferred. This preference is due to its reduced likelihood of water intrusion. The SSCC-RSSF would be next in preference and the Drywell last. The Drywell is least favored of the single canister concepts because it is below ground level and minor flooding could provide a source of water. The above ground casks would require a major flood or severe cask damage coupled with heavy precipitation to provide a water source.

of the multiple canister concepts (excepting WBC), for the intact fuel rod cases the DWSC-2 is preferred. A11 concepts have essentially equal reactivity for a complete flood condition. The DWSC-2, however, has the lower reactivity for the canister flooded, inter-canister space dry condition. The ACVC shows a higher reactivity than the SSCC-2 for this condition. Both, however, could have a criticality safety problem for this condition. The case of essentially dry canisters with interspersed water poses no problem for the DWSC-2 or the SSCC-2. This condition could be a potential problem for the ACVC. Therefore the second preference would be the SSCC-2 and last the ACVC. For intact fuel rods all concepts are potentially viable. The SSCC-2 and ACVC may be questionable, however.

For the disintegrated fuel rod case all of the concepts have a potential safety problem. A $13-i n$. diameter cylinder of $3.5 \mathrm{wt} \%$ enrichment $\mathrm{UO}_{2}$ in water at $2400 \mathrm{~g} \mathrm{UO}_{2} / l$ with water reflection is critical. A cylinder diameter of ten inches or less would be required to achieve an accepted reactivity under these conditions. The case could be made that the single canister concepts need not have full water reflection, however the reduction in reactivity would not be sufficient to render an acceptable reactivity value 
at the 13-in. diameter. From the standpoint of criticality safety none of the concepts as described (except WBC) would be acceptable unless:

- Disintegration is shown to be incredible, or

- Water intrusion is shown to be incredible.

There exists a potential that significant canister redesign and/or changes in the basic assumptions $(a)$ could yield an acceptable design even if the two items above cannot be met.

None of the concepts can match the WBC in preference from the criticality safety viewpoint. The fact that storage in WBC currently exists is a factor, but its immunity from the disintegration problem is its major advantage.

(a) Allowing credit for fuel burnup is the most notable candidate. 


\section{REFERENCES}

1. Spent Unreprocessed Fuel Facility Engineering Studies. RHO-LD-2, Rockwe11 Hanford Operations, October 1977.

2. L. M. Petrie and N. F. Cross, KENO-IV, An Improved Monte Carlo Criticality Program. ORNL-4938, Oak Ridge National Laboratory, November 1969.

3. C. R. Richey, EGGNIT: A Multigroup Cross Section Code. BNWL-1203, Battelle, Pacific Northwest Laboratories, Richland, Washington, November 1969.

4. A. B. Johnson, Jr., Behavior of Spent Nuclear Fuel in Water Pool Storage. BNWL-2256, Battelle, Pacific Northwest Laboratories, Richland, Washington, September 1977.

5. Reactor Physics Constants. 2nd Edition, ANL-5800, Argonne National Laboratory, JuTy 1977.

6. K. R. Ridgway and R. D. Carter, Criticality Prevention Parameters of Plutonium in Soils. ARH-2622, Atlantic Richfield Hanford, October 1972. 
APPENDIX A

COMPOSITION OF REFLECTORS 


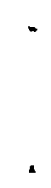




\section{COMPOSITION OF REFLECTORS}

\section{Composition of Reflectors}

\begin{tabular}{|c|c|}
\hline Element & Atom Percent \\
\hline$H$ & 10.43 \\
\hline 0 & 58.43 \\
\hline $\mathrm{Na}$ & 1.396 \\
\hline $\mathrm{Mg}$ & 0.199 \\
\hline $\mathrm{Al}$ & 3.258 \\
\hline Si & 21.06 \\
\hline$k$ & 0.924 \\
\hline $\mathrm{Ca}$ & 3.885 \\
\hline $\mathrm{Fe}$ & 0.417 \\
\hline
\end{tabular}

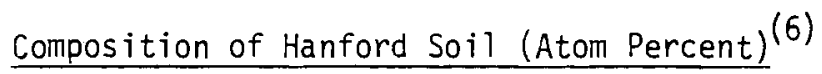

\begin{tabular}{|c|c|c|c|}
\hline Element & Dry Soil, No Voids & 30 Volume $\% \mathrm{H}_{2} \mathrm{O}$ & 40 Volume $\% \mathrm{H}_{2} \mathrm{O}$ \\
\hline$H$ & 0.0 & 24.90 & 32.07 \\
\hline 0 & 65.10 & 53.23 & 49.82 \\
\hline $\mathrm{Si}$ & 27.87 & 17.46 & 14.46 \\
\hline$A 1$ & 2.460 & 1.542 & 1.277 \\
\hline $\mathrm{Fe}$ & 1.094 & 0.685 & 0.567 \\
\hline $\mathrm{Ca}$ & 1.914 & 1.799 & 0.993 \\
\hline $\mathrm{Na}$ & 0.541 & 0.339 & 0.281 \\
\hline $\mathrm{Mg}$ & 1.022 & 0.640 & 0.531 \\
\hline
\end{tabular}


APPENDIX B

GEOMETRY MODELS FOR STORAGE CONCEPTS 
The following six figures show the geometry models used in the calculations performed as part of the criticality safety comparison for the spent fuel storage concepts. Each concept is represented once. Other reflector conditions were assumed for each concept but one figure is sufficient to demonstrate the approach used. 


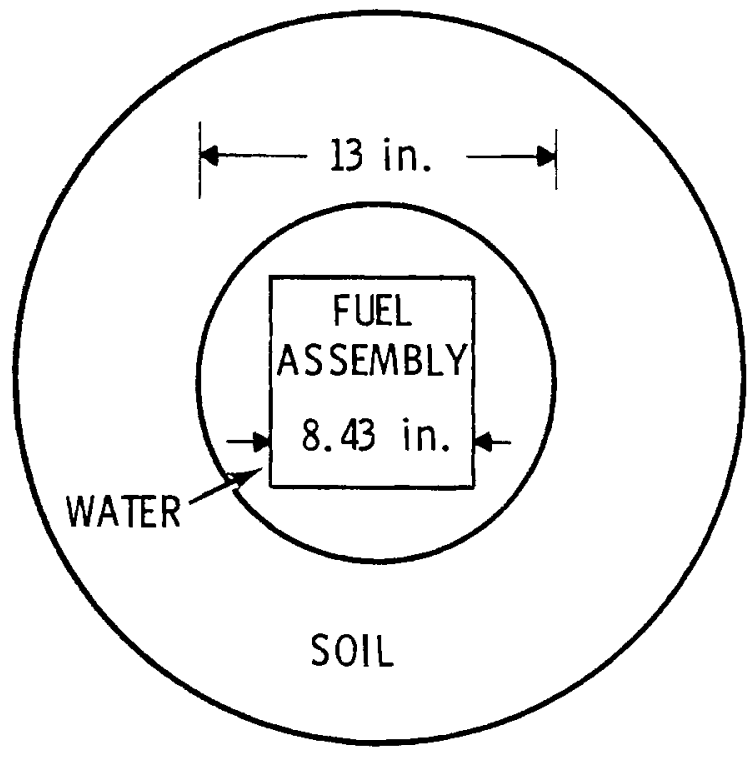

FIGURE B-1. Drywe11 Geometry Mode1, Flooded

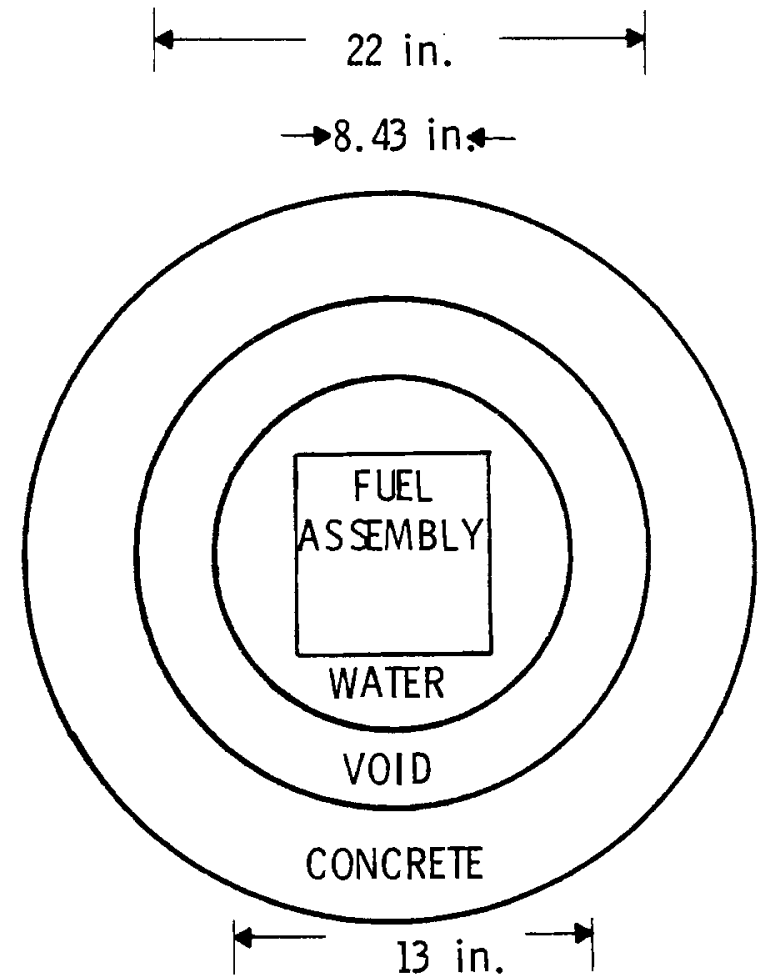

FIGURE B-2. SSCC-1 Geometry Mode1, Canister Flooded 


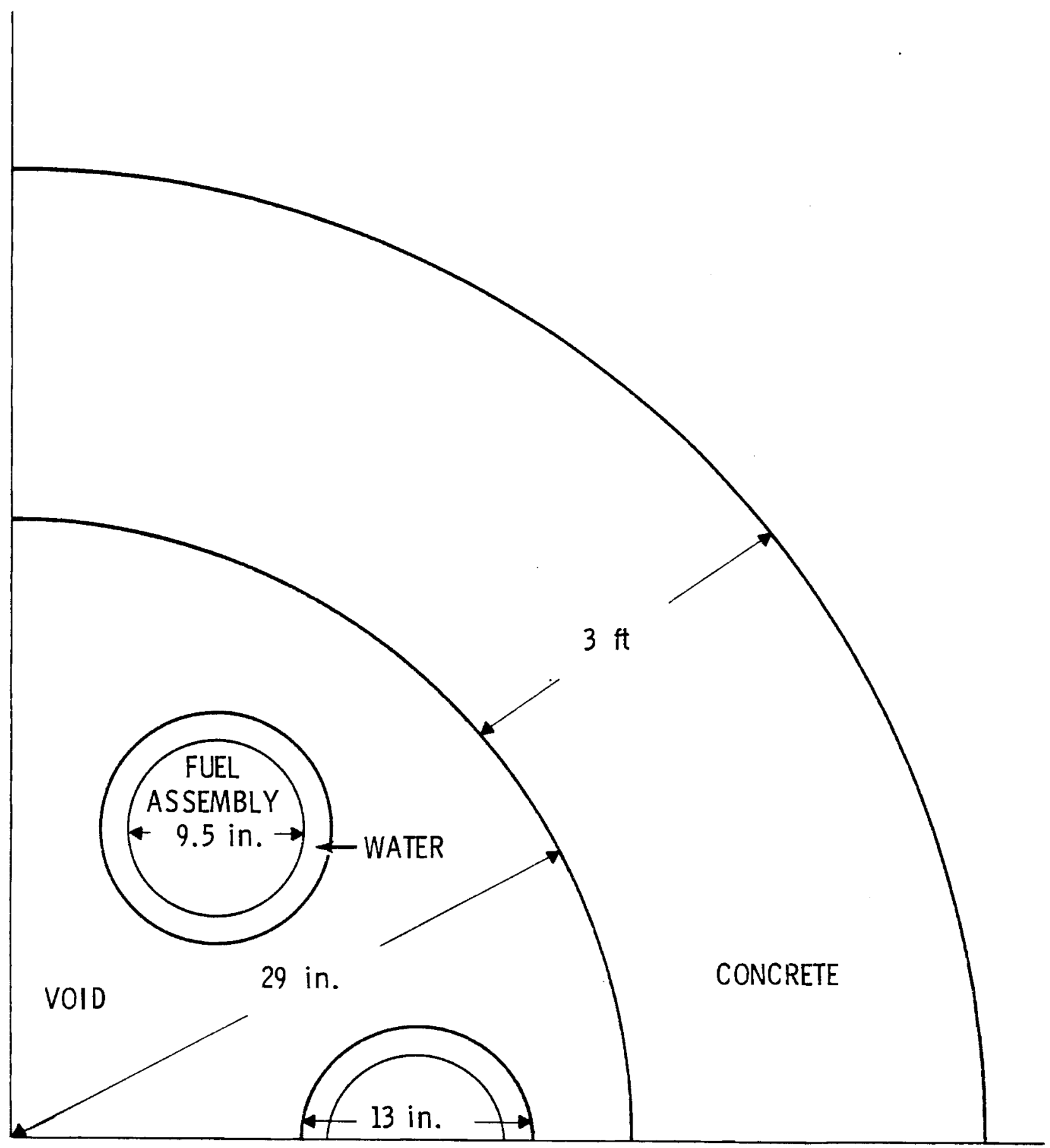

FIGURE B-3. SCCC-2, Geometry Mode1, Canisters Flooded 


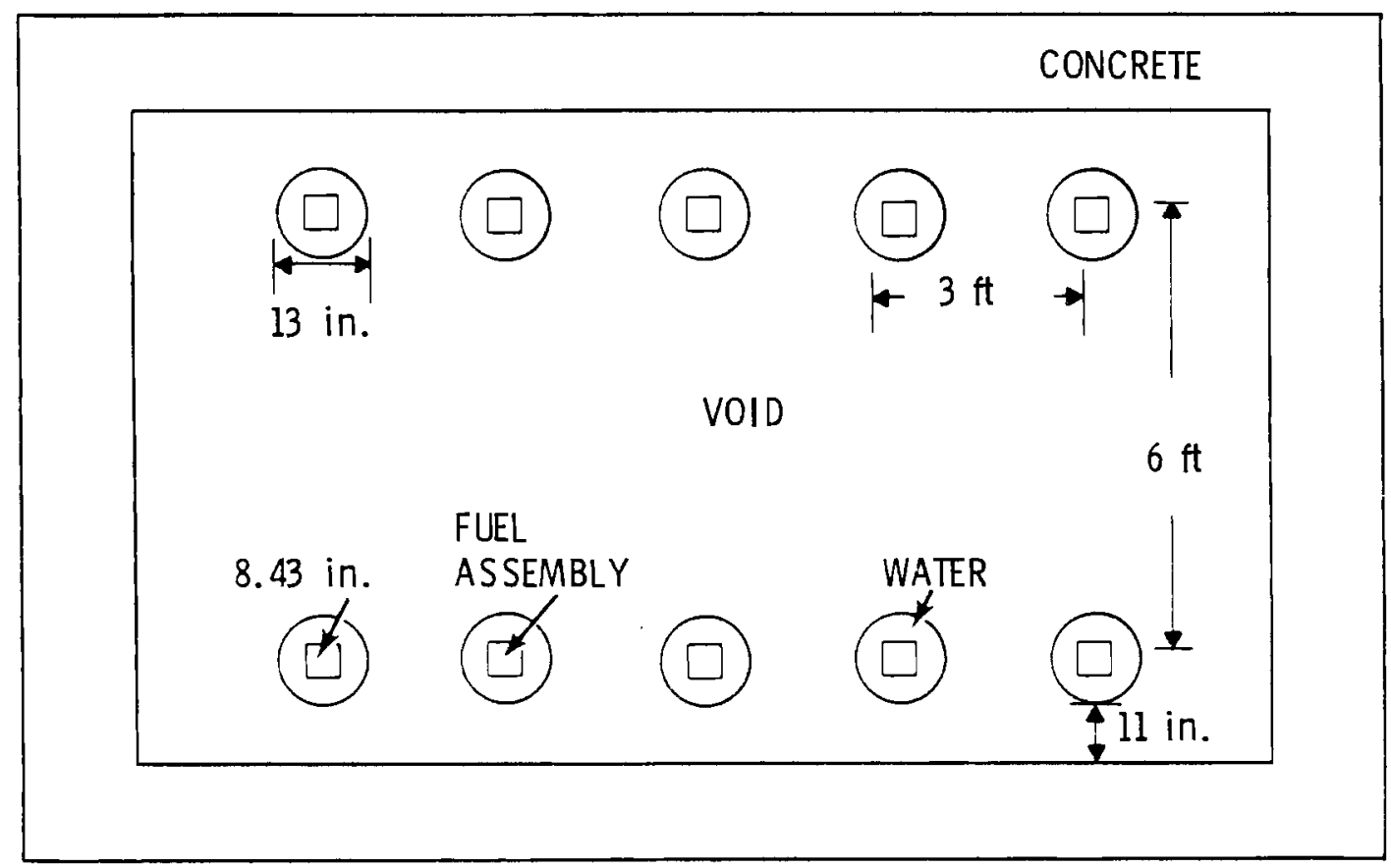

FIGURE B-4. DWSC-2 Geometry Mode1, Canisters Flooded

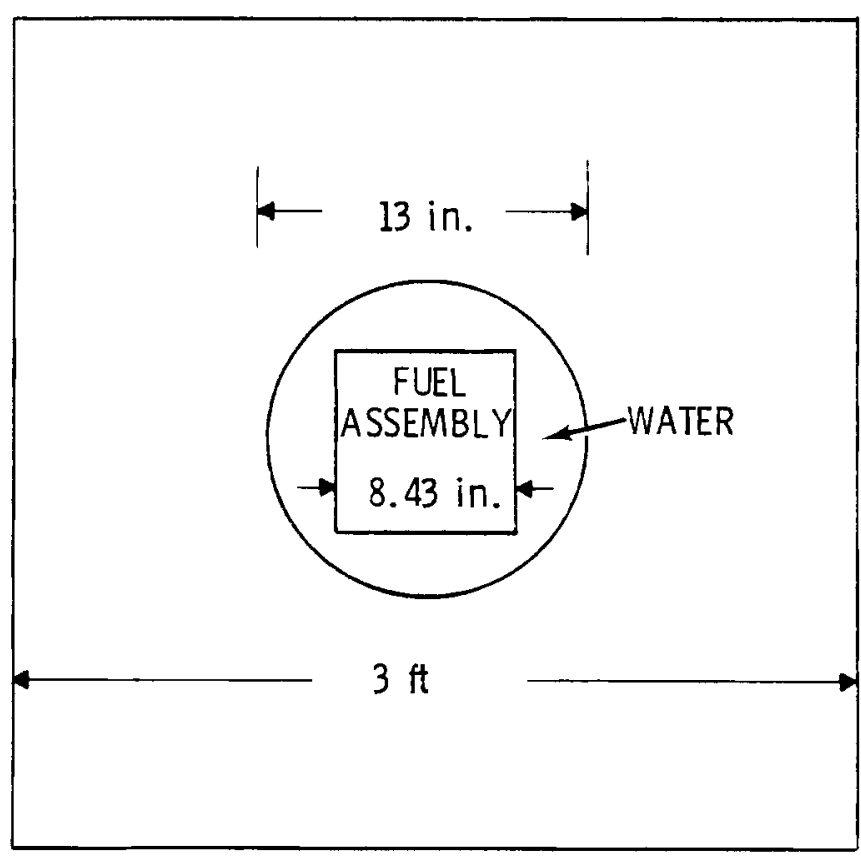

FIGURE B-5. ACVC Geometry Mode1, One Flooded Canister (PWR) 


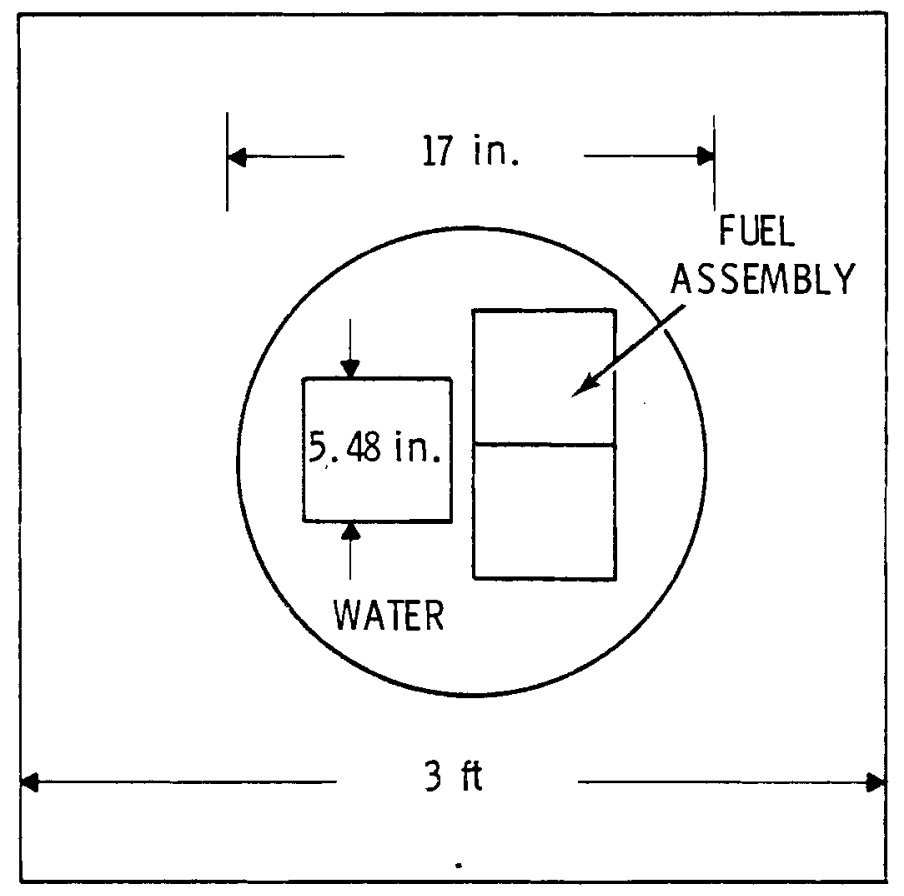

FIGURE B-6. ACVC Geometry Mode1, One Flooded Canister (BWR) 


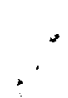

1 


\section{DISTRIBUTION}

No. of

Copies

\section{OFFSITE}

A. A. Churm

U.S. DOE Chicago Patent Group Chicago Operations office 9800 South Cass Avenue

Argonne, IL 60439

27 U.S. DOE Technical

Information Center

C. R. Cooley

U.S. Department of Energy, Headquarters

Washington, DC 20545

J. B. Work

U.S. Department of Energy, Headquarters

Washington, DC 20545

2 A. Roberts

U.S. Department of Energy, Nevada Operations Office

P.0. Box 14100

Las Vegas, NV 89114

R. D. King

U.S. DOE Savannah River Operations Office

P.O. Box A

Aiken, SC 29801

F. L. Harris

Kaiser Engineers, Inc.

300 Lakeside Drive

Oakland, CA 94666

2 D. C. Durril

Westinghouse Electric Corp.

Advanced Energy Systems

Division

P.0. Box 708

Mercury, NV 89023
No. of

Copies

2 J. B. Wright

Westinghouse Electric Corp.

Advanced Energy Systems

Division

P.0. Box 10864

Pittsburgh, PA 15236

ONSITE

5 Hanford Engineering Development Laboratory

3

D. A. Cantley

J. F. Fletcher

R. L. Knecht

6

U.S. Department of Energy, Richland Operations Office

W. E. Cawley

O. J. Elgert

P. G. Harris

F. L. Goldsberry

R. B. Goranson

H. E. Ransom

7 Rockwell Hanford Operations

W. J. Kurzeka

D. A. Turner

D. D. Wodrich

Pacific Northwest Laboratory

2

3

I. S. Levy

R. C. Lijkala

R. D. Widrig

L. D. Williams

R. E. Westerman

C. L. Brown

E. D. Clayton

5

G. P. Selby

10

S. W. Heaberl in

M. K. White

W. K. Winegardner

D. E. Larson

Technical Information

Publishing Coordination 

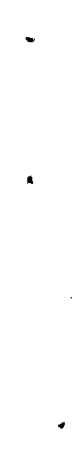